\title{
Economic Change and Occultic Sika Bone: Market Women's Responses to Increased Financialization in Ghana
}

\author{
Jovia Salifu (1)
}

\begin{abstract}
Set in a context where material accumulation is valorized, this article analyzes narratives of sika bone (bad money) as expressions of economic uncertainty by market women operating in an era of increased financialization. The ethnographic evidence supports previous arguments about the impact of economic change in this millennium, a change that fosters both rationality and superstition in equal measure. Salifu proposes that sika bone indicates a sense of uncertainty fostered by economic change in the supply of cash and formal credit, a sentiment that is expressed by applying old notions about occultic means of accumulation to new and equally enigmatic circumstances.
\end{abstract}

Résumé: Placé dans un contexte où l'accumulation matérielle est valorisée, cet article analyse les récits de sika bone (le mauvais argent) en tant qu'expressions de l'incertitude économique du marché des femmes opérant dans une ère de financiarisation accrue. Les preuves ethnographiques soutiennent les arguments précédents sur l'impact du changement économique de ce millénaire constitue un changement qui favorise à la fois la rationalité et la superstition dans une mesure égale. Salifu propose que le Sika bone indique un sentiment d'incertitude encouragé par le changement économique dans l'offre d'argent liquide et de crédit formel, un

African Studies Review, Volume 64, Number 4 (December 2021), pp. 938-958

Jovia Salifu is a lecturer at the Centre for African Studies, University of Education, Winneba (Ghana). His recent publications include "Kinship and Gendered Economic Conduct in Matrilineal Offinso, Ghana" (Africa, 2020) and "You Have a Lot to Answer For': Human Rights, Matriliny, and the Mediation of Family Conflicts at the Department of Social Welfare in Ghana" (Political and Legal Anthropology Review, 2021).E-mail: salifuj@gmail.com

(C) The Author(s), 2021. Published by Cambridge University Press on behalf of the African Studies Association. This is an Open Access article, distributed under the terms of the Creative Commons Attribution licence (https:/ / creativecommons.org/ licenses/by/4.0/), which permits unrestricted re-use, distribution, and reproduction in any medium, provided the original work is properly cited.

doi:10.1017/asr.2021.88 
sentiment qui s'exprime en appliquant de vieilles notions sur les moyens occultes d'accumulation à des circonstances nouvelles et tout aussi énigmatiques.

Resumo: Debruçando-se sobre um contexto de valorização da acumulação material, este artigo analisa as narrativas do sika bone (dinheiro mau) enquanto expressões da incerteza económica por parte de mulheres vendedoras de mercado que trabalham numa época de financeirização crescente. Os dados etnográficos factuais dão fundamento aos argumentos que têm sido defendidos quanto ao impacto das alterações económicas neste milénio, alterações essas que promovem simultaneamente a racionalidade e a superstição. Salifu sugere que o sika boneé revelador de um sentimento de incerteza criado pelas mudanças económicas que se têm verificado na circulação de dinheiro e na atribuição de crédito formal, sentimento que é expresso através da aplicação de velhas noções dos meios ocultos de acumulação a novas e igualmente enigmáticas circunstâncias.

Keywords: economic change; market women; bad money; financialization; Ghana

(Received 20 January 2020 - Revised 19 July 2021 - Accepted 21 July 2021)

\section{Introduction}

In the course of our interviews, the market women in the Asante town of Offinso with whom I spoke told me about their fear of unscrupulous buyers presenting sika bone (bad money) when they bought things. This tainted money, when added to the trader's clean money, would cause all the money to mysteriously disappear or become worthless, they told me. To prevent this, market sellers added various ritual objects such as a piece of charcoal and pepper to their money to neutralize the potency of any bad money that might be given to them. Others performed secret rituals at the places where they sold or at special sites such as crossroads or where footpaths met. Similar practices have been observed in other parts of Africa. For instance, in central Malawi, sellers may be exposed to chitaka, an occultic force that enables buyers to siphon money from their unsuspecting victims, and those hoping to mitigate this force must either resort to a temporary distribution of their money to close relatives or place ritual objects in their money bag (Englund 1996:270).

Such beliefs about the magical attributes of money have featured prominently in the economic history of West Africa and have "coexisted with routine numeration since at least the fifteenth century" (Guyer 2004:11). These notions point to a perceived link between the spiritual and the material worlds, a link that allows spiritual interference in the material efforts of people. For example, William Olsen (2002) has noted how twentieth-century Asante witchcraft narratives were steeped in a belief in the ability of witches to destroy the material fortunes of their victims.

In the context of the new millennium, Joseph Oduro-Frimpong has similarly written about the strong association between religious belief and 
material practices in the many tales of sika duro (ritual money) which circulate in the Ghanaian public space. These stories of ritual money influence people's behavior, to the extent that

shop owners and market men and women typically refuse to do business with persons whose wealth is suspect, or else they are careful not to mingle any currency received from such individuals with their existing assets. The threat is a spiritual siphoning away of one's wealth and a collapsed business. (Oduro-Frimpong 2014:136)

Anthropologists have long been drawn to this puzzling belief in the connection between the occult and modernity (Geschiere 2015). Historically, these sorts of narratives have been associated with major economic change. For example, Olsen's (2002) analysis of witchcraft accusations indicates that the activities of witch-finding cults intensified at the turn of the twentieth century, when cocoa cash cropping was taking off and Asante became fully absorbed into the British imperial economy. Around this time also, the introduction of the imperial currency and the widespread availability of European goods in Asante communities sparked considerable concern about the excessive monetization which, according to some commentators, had "spoiled Ashanti" (McCaskie 2000:126). These concerns were fueled by a rise in what was perceived as "nkonnode" (unbridled consumption), and "From this perspective money in a community was said to be like 'feathers in a fire' (hye takraw gyamu), an element that destabilized the whole by over excitation of its parts" (McCaskie 2000:126). In cases such as these, the beliefs and accompanying behaviors of people constitute a response to the effects of broader economic forces impacting on life in these places, whether it is the introduction of cocoa cash cropping in early twentieth-century Asante (Olsen 2002), or the influx of "petro-naira" from the new oil industry in Nigeria (Barber 1982:431), or post-apartheid neoliberal economic policies in South Africa (Comaroff \& Comaroff 1999).

In the current economic climate, scholarly attention has been drawn to the contradictions of a hegemonic neoliberal capitalism which appears to offer opportunity to all and yet overlooks many in the access to economic opportunities (Comaroff \& Comaroff 2001). Under this regime, the administration of conduct by both state and non-state actors, including "statesmen, trade-unionists or bosses," is aimed toward producing entrepreneurial subjects who will thrive in the competitive environment that is created (Lazzarato 2009:114). Thus, the "homo oeconomicus sought after is not the man of exchange or man the consumer; he is the man of enterprise and production" (Foucault 2008:147). In the contemporary neoliberal state, debt (and the pressure to repay loans) functions as one of the means by which the required lifestyle is produced (Lazzarato 2009:127), although attempts at neoliberal governmentality can be expected to function less effectively in Ghana, where the mechanisms of surveillance are not as well developed as in Western countries (Ferguson 2009:173). Nonetheless, one form of response to the 
economic conditions produced by this version of neoliberal capitalism has been an increase in narratives about the occult and its impact on the material world (Comaroff \& Comaroff 2001:2).

Drawing on thirteen months of ethnographic fieldwork, this article analyzes the ways in which market women make use of narratives of sika bone in their response to economic change in an era of the rapid expansion of banking services and the accompanying pressures to conform to a neoliberal work ethic. It reflects on how market women manage the uncertainties that come with their handling of cash, debt, and savings in a context where ideal economic success has historically been gauged by the image of the "big man" or sbirempon (McCaskie 1983:27); a context where social ranking has historically been pegged on economic achievement (Adebayo 2007; Guyer 2004). The subjects of this article are market women who receive loans ranging from GHS200 (USD34) to GHS2000 (USD336) in six- or twelve-monthly cycles. Some of them sell cooked food or foodstuff such as yams, palm nuts, flour, and fruits. Others sell general provisions such as processed foods, used clothing, and household items like charcoal or mortars. They typically operate at levels ranging from the "smallest-scale retailers... willing to sell sugar by the cube or three small tomatoes or a handful of beans" (Clark 2016:3) to the small wholesalers. Many of them have expertise in selling more than one item, and this becomes beneficial when they have to cope with seasonal change. For example, a fruit seller must be prepared to switch to either cooked food or some other trade when fruits are out of season or become more perishable due to a change in weather conditions. Such changes in trade items are also sometimes precipitated by loss of capital or a major life change such as starting a family.

\section{Market women and economic change in Ghana}

Many studies of market women in West Africa have highlighted the ambition of traders to accumulate wealth for the material and social benefit of themselves and their dependents (Clark 1994; Wan 2001). For example, Akosua Darkwah (2007) demonstrates through her study of traders in Accra the level of prestige that can accrue to successful market women in Ghana. Similarly, Mimi Wan (2001), in her study of gari traders in Ibadan, has shown how women traders aspire to accumulate following the example of nineteenthcentury big men by expanding their influence in the social space through material acquisition and distribution. The techniques adopted in pursuit of this goal have been developed and refined in the market over a long period of time (Robertson 1974). However, the economic reality for most traders is rather bleak, as they face several obstacles in their quest for accumulation.

In the historical context of Ghana, the impact of neoliberal economic change on market women has often been traced to the mid-1980s, when the Structural Adjustment Program was first adopted. The prelude to this was the dramatic implementation of economic regulation and later deregulation under the military regimes of the 1970s and early 80s (Clark 1994). Regulation in the 1970 s and early 80 s took the form of price, exchange, and import 
controls which were periodically enforced through crackdowns. The inevitable result was the development of illegal channels of distribution alongside the approved channels (Clark 1994:377). Acting on populist misconceptions about the role of market women in the economy, the militarized state attempted to destroy the market system altogether by bypassing traders in the chain of distribution (Clark 1994; Clark \& Manuh 1991; Robertson 1983). Despite the harassment of market women and the physical destruction of marketplaces, women traders remained integral to the distribution system in Ghana. Claire Robertson (1983) has accordingly argued that market traders became indispensable because of their role in creating and participating in a distribution system that suited the social and economic context of Ghana. The attempts to dislodge them only underlined their crucial role in the economy.

The worsening economic crisis of the 1980s precipitated the adoption of a neoliberal approach in the form of the Structural Adjustment Program proposed by the World Bank. In their chapter on the impact of structural adjustment on Ghanaian market women, Gracia Clark and Takyiwaa Manuh (1991) made the point that the new policy did not create the economic uncertainty in which market women found themselves, but rather it accentuated the crises they were already involved in. By this time, market women were already familiar with the challenges of coping with the effects of a declining national economy, price controls, and open hostility from the state toward them (Robertson 1983; Clark \& Manuh 1991; Clark 1994). The feeling of uncertainty and lack of control over the conditions of their economic activities was therefore a climate that was only further exacerbated by structural adjustment. In general, structural adjustment affected women disproportionately due to the preexisting gender inequalities in African countries in terms of access to the means of production (including credit), labor demands, and control of surplus (Due \& Gladwin 1991).

In Ghana, specific structural adjustment measures included the devaluation of the currency, reduction in government expenditure (including public sector wages), and an emphasis on the production of tradeable goods that fetch foreign exchange (Clark \& Manuh 1991). The consequences of these policy changes were massive job losses in the public and formal private sector, higher costs of public services, and price increases. Farmers and traders of local produce were directly affected by the price hikes and competition from imported products. Traders were also affected by falling demand, lack of capital, and the high cost of living. Indeed, since the 1980 s, currency fluctuation and declining exchange rates have generally affected earnings and the concomitant social ranking that derives from economic achievement (Adebayo 2007). Market women largely viewed the implementation of neoliberal economic policy as a negative development. For instance, the policies that induced the withdrawal of subsidies on essential public services and general job losses under structural adjustment were considered by the market women to be counter-intuitive and contrary to their understanding of good accumulation as something that must ultimately benefit the community (Clark 2009). 
The effects of structural adjustment have continued to be felt decades after it was first introduced. Currency fluctuation and import dependency have contributed to the uncertainty faced by traders. Akua Britwum (2013:55) has noted how tomato farmers and sellers in urban markets in Ghana have had to endure the negative impact of import tariff reduction and the consequent closure of tomato processing factories in the country. As a result, the trade in fresh and processed tomatoes has become internationalized, with its attendant deleterious effects on both farmers and traders. For example, the sourcing of fresh tomatoes from neighboring Burkina Faso has put traders at loggerheads with the farmers who have lost out to their foreign competition. In situations such as this, urban market women have been able to turn to self-help associations, which are usually organized around specific commodities with the aim of helping to regulate the trade, provide welfare services, and lobby government agencies on behalf of traders (Britwum 2013).

Although the effects of forceful regulation and later deregulation under structural adjustment were felt by all market women, it is important to note that different kinds of traders experienced the changes differently. In terms of the violent enforcement of regulation, whereas the more successful traders could avoid harassment and physical abuse by staying away from the market, some of the smaller traders had no choice but to brave the consequences of coming to the market. When things had calmed down, the big traders could resume trading later with the savings they had made, while the smaller ones had more difficulty going forward (Clark \& Manuh 1991:226). Furthermore, while currency fluctuation and trade liberalization have generally had negative consequences, there are categories of persons who have been able to benefit (Adebayo 2007). Traders in what has been described as "global consumer items" have been able to benefit the most from the removal or reduction of import tariffs (Darkwah 2007:207). Thus, even though most traders lost out, those who could meet the capital demands were able to carve out opportunities in the relatively prestigious trade in high-end imported products. But even this cohort has had to contend directly with issues of currency devaluation and the exchange rates of the Cedi against foreign currencies, which affect their profit margins. When the exchange rates work in their favor, they can reap the occasional windfall, but this is rarely the case (Darkwah 2007).

Despite facing these existential challenges, market women have generally managed to survive the threats to their livelihood, be it in the form of open hostility from the state or "international capitalism" (Robertson 1983:485). Clark has demonstrated through her work with elderly Asante traders that the expertise required to assess and cope with economic changes and uncertainties is developed over many years of practice. At all times, the decisions about what type of trade to get into are informed by a careful assessment of the prevailing economic conditions, and this enables market women to switch between trades when the conditions demand it (Clark 2009). 
Throughout this period, the various responses of market women to economic change have been underpinned by a sense of resilience and flexibility which enabled them to survive through the tough times. Sometimes their responses have been pragmatic, such as the time when market women in Accra stood by powerlessly "in the face of the arbitrary acts of government" (Robertson 1983:476). At other times, the traders have defied the rules by creating unapproved channels of trade, like when Kumasi traders circumvented price control measures by moving their activities to "clandestine locations" (Clark 1994:385). Their responses to neoliberal policies have also been ambivalent, with some classes of traders benefiting from the withdrawal of price and import restrictions (Darkwah 2007) while others labor under the weight of competition from imports and a generally unstable economy (Britwum 2013). The legacy of violent regulation and deregulation has been a deepening of the mistrust of national economic policies by market women (Clark 1994).

In the case of the market women in Offinso, narratives of sika bone signal a similar sense of uncertainty and mistrust, although this time, of free market forces manifesting in the supply of formal credit, cash, and savings. One contrasting experience between my interlocuters and market women in the previous economic epochs is their access to credit facilities. Gaining access to formal credit has been a longstanding problem for market women in Ghana, leaving some with no option but to contract loans from usurious moneylenders and risking being trapped in permanent debt (Robertson 1983). Clark and Manuh's survey results from markets in Kumasi and Accra in 1989-90 showed that about 90 percent of traders lacked access to institutionalized credit, and those who had access complained about such conditions as high interest rates, credit limits, and the requirement for savings (1991:230). Comparing that situation to the present, microcredit has become much more accessible to market women. The current expansion of financial services has presented market women with new opportunities to gain access to credit to augment their trading capital. At the same time, increased financialization has brought with it a different set of challenges. The high interest rates are still a problem, in addition to the pressures of adhering to strict payment deadlines. Compounding these challenges further is the recent proliferation of dubious financial institutions, some of which have caused market women to lose all of their savings.

\section{Market women and the inexplicable loss of profits}

With an estimated population of over fifteen thousand in the last national census in 2010, Offinso is the most urbanized settlement in the Offinso municipal area. It is served by three main markets: New Town Market, Kokote Market, and Abofour Market. Offinso New Town Market is located in the center of town, surrounded by the important suburbs of Old Town, Agyeimpra, Asamankama, Dentin, and Kokote. Unlike the other markets, the New 
Town Market has no stipulated market day. A small group of traders turns up every day to sell to the residents of that part of town. Kokote Market is also open daily, but it is only at its fullest capacity on Sundays, when traders come from Kumasi and the surrounding areas. Kokote is the main retail market in Offinso. The other important nearby commercial town that has an impact on daily life in Offinso is Abofour, which is best known for its busy wholesale market. Abofour Market only comes alive on Thursdays, with trading activities spilling over onto the main tarred road that runs through town, causing dangerous traffic conditions. This is where the big traders offload truckloads of farm produce sourced from the hinterland, and where the smaller traders come to restock their wares. It is where small and large traders interact with each other the most, haggling and quietly making credit or debt arrangements. The proximity of Offinso to Kumasi means that traders from the big city are regulars at both Kokote and Abofour Markets, just as Offinso traders also have ease of access to the vast urban market of Kumasi within half an hour via road $(35 \mathrm{~km})$.

Spending time in all these major markets in Offinso provided me with the opportunity to interview the market women and observe how they conducted their affairs. For a core group of thirty women, I conducted follow-up interviews and observations in their homes and as they attended group meetings at the offices of formal lending institutions. There were also oneoff interviews with twenty other women outside this group and with some of the loan officials, as well as with local government employees who implemented projects to support the commercial activities of women. As a relatively younger male Ghanaian, I was able to interact with most of the women from a position of a son who was interested in writing about their activities for my school learning purposes. I occasionally faced questions about the expected impact of my research on their activities. But I was careful to emphasize that my study was primarily for academic purposes and not linked to any commercial or banking institution. It became even more important for me to clarify this when I began to volunteer for a small financial non-governmental organization (NGO) six months into my stay in Offinso. The women's curiosity about my possible affiliation with a lending institution was indicative of a constant search for new and better lending conditions. As will be demonstrated shortly, this behavior was symptomatic of a very fluid fiscal environment in which the women and the financial institutions functioned.

From my observations, it seemed as though the working life of a trader tended to be a roller coaster journey of alternating buoyant peaks and bleak dips in relatively quick succession. These uncertainties reflected on the market scene, as stories of sika bone circulated among the traders. Among the women themselves, there was a fundamental understanding of money as something that was fleeting, erratic, and unpredictable. Unlike Andrew Walsh's (2003:290) Madagascan sapphire miners who felt the need to expend "hot money" as quickly as possible because of its supposed worthlessness in the long term, the challenge for the Offinso market women was to try to hold on to money that they feared could always slip away unnoticed. 
At our first encounter, Tiwaa (a trader in her forties) was the influential leader of a women's loan group of eight members. As the group leader, she controlled recruitments and dismissals from the group. At the end of the loan cycle, she could drop anyone who was not punctual with her payments and replace her with another person of her choosing. She also had the task of collecting weekly payments from the other group members and communicating with the bank on behalf of the group. On occasions when her group members were unable to make their payments on time, she had to put up her own money to comply with the strict deadlines of the bank and retrieve it later from the group. This meant that she had to be making a healthy profit to provide such cover for her group members. At GHS1500 (USD252), her loan amount was the largest in the group, and she was very influential with the group members and bank officials. One time when I asked her what she planned to do with the group members who were not punctual with their payments, she replied, eager to highlight her influence with the bank officials:

I will not let the bank manager increase their money [next loan]. They will stay there ... I will tap her [the bank official] on the shoulder and say, add to this person, don't add to that person. ${ }^{1}$

It is safe to say that at this point Tiwaa was relatively successful in her trading and influential in her group as well as at the bank. Months later, by the midway point of my fieldwork, I noticed that she was having financial difficulties. The first sign was when she started borrowing yams from other traders to sell, a far cry from when she herself loaned yams to other traders. Before long, she started chasing after more loans from other financial institutions. I knew of other women who did this as a strategy to pay old loans that were due. This was done in the hope that by the time the new loan was due, they would have raised enough money to settle it. By the time I was leaving, she could barely keep up with her weekly loan payments. She admitted to this, telling me, "Now my reputation is ruined, my stock is low at that bank."2

Her yam business had faltered, and she dabbled briefly in selling cooked food before switching completely to peddling cold drinks at the tollbooth on the road to Kumasi. In the space of a year, she had gone from being a reliable client of the microcredit institution to being a trader who was barely scraping by. Her experience was not unique. Other traders went through similar cycles of growth and recession. Another such person was Akua, who was first introduced to me as one of the best clients of Hope International, the financial NGO for which I was volunteering. Women who took loans from this NGO were expected to graduate to the traditional banks after a few years of receiving low interest loans from the NGO. Akua was deemed to have successfully done this. But a few months later, I was surprised to find that she was back to where she started, with Hope International.

How are we to make sense of such rapid changes of fortune? As a researcher observing Tiwaa's activities for the period that I was there, I could 
try to attribute her losses to unsound business decisions and unforeseen family expenses. Maybe she would have been better off sticking to one trade. But the explanations she gave me, that the yam rotted more easily in the hot season and that it was more capital intensive, seemed reasonable. She obviously knew the intricacies of her trade better than anyone, especially me. In any case, this strategy of switching between trades has been a long-standing practice among market women in Ghana and West Africa (Clark 2004). Another possible explanation was that perhaps her stock dwindled because of an increase in her financial burden within her household, which meant that her money went into unplanned expenses. But this would just be speculation on my part. So how did she herself explain her situation?

\begin{abstract}
With money, anything can happen. You can take money and go on one or two trading trips, and everything will perish (hye). When this happens, and you worry (dwene) too much, you can become sick. The mind can affect the body, and you cannot even work again. So, when there is a loss, you must pray for God's help to recover. You can take some yams from your sister ( $n u a)$ to sell, return her money to her and use the little profit from it to pay for the loss. You cannot be ashamed of a loss. If you are ashamed or worry too much, you will die and leave your children behind. So, anything can happen, such is life... the money just finishes ( san koraa), leaving nothing in my hands. Sometimes I go to my friend and say, give me hundred tubers of yam to sell. I then use the little profit to cover the loss. ${ }^{3}$
\end{abstract}

The change in Tiwaa's fortune was quite rapid. In a few months, she had moved from confidently tapping the microfinance official on the shoulder and instructing her to "add to this person, don't add to that person" to admitting that her reputation was "ruined" at that institution. This is a good illustration of the uncertainty surrounding the participation of market women like Tiwaa in the broader economy of cash and debt. Having received small loans from microfinance institutions, they are faced with the challenge of generating enough profits to repay the loans with interest in the time stipulated by the lenders while juggling their routine expenditures for the upkeep of their families. The high interest charged on loans and the insecurity of savings also contribute to the economic uncertainty of market women. It is no wonder that sometimes it feels like the money "just finishes."

\title{
Managing debt and savings in an era of rapid financialization
}

For a country of its size, Ghana has a very vibrant formal microcredit sector consisting of thousands of financial institutions including rural and community banks, microfinance institutions (MFIs), savings and loans companies, financial NGOs, credit unions, registered money lenders, and registered susu (savings) collectors. Many of these institutions are organized under the Ghana Microfinance Institutions Network (GHAMFIN), the umbrella association of all institutions which operate in this sector. In line with global 
trends, most of these institutions target women (Garikipati et al. 2017:641) and operate in ways that are distinctly neoliberal (Norwood 2011:170). The lending programs that target women usually focus on encouraging entrepreneurship and an individualized strategy in the market, so that borrowers can expand their incomes and repay loans promptly to keep the institution financially viable (Mayoux 2001:438; Chant \& Sweetman 2012:518). This approach puts borrowers under pressure to maximize their profits and adhere to strict repayment timelines.

The recovery of loans is the primary goal of lending institutions, and microcredit research in different parts of the world has indicated the length to which these institutions go to ensure their profitability (Van den Berg et al. 2015:1243). Charging high interest on loans is perhaps the most reliable means of ensuring the financial sustainability of microcredit programs. In Ghana, the average interest charged on microcredit is 25 percent, with some MFIs charging as much as 78 percent, a rate that has been described by some researchers as "poverty enhancing” (Dary \& Issahaku 2013:448). According to these researchers, given the prevailing economic conditions in Ghana, an interest rate of between 18 percent and 20 percent would be enough for MFIs to remain profitable, even though most of them charge a higher rate. From the point of view of the MFIs, these measures are necessary because they must be financially viable enough to satisfy the interests of their profit-oriented backers or partners (Valencia-Fourcans \& Hawkins 2015:4). The way to ensure this is by lending to highly profitable clients who function in accordance with a neoliberal rationality.

This "smart economics" approach, which assumes that increasing the entrepreneurial capacity of women will not only result in the cost-effective delivery of microcredit, but also automatically improve gender equality as a residual effect, has gained currency in the world of international development, under the patronage of institutions such as the World Bank (Chant \& Sweetman 2012:519). Both corporate and development agents have been united on this bandwagon by their commitment to harnessing the productive potential of women around the world (Cornwall \& Rivas 2015:406). Even the Millennium Development Goals on gender reflect this thinking, although they attract criticism for their preoccupation with "making women work for development, rather than making development work for their equality and empowerment" (Cornwall \& Rivas 2015:398). In Ghana, the neoliberal outlook of the lending institutions is complementary to the efforts of the state to draw the population into the banking and regulatory system (Breckenridge 2010:643).

In Offinso, every lending institution provides its own separate orientation program for new clients, and some of them rely on the Business Advisory Center (BAC) to facilitate the training. The BAC is the local government agency that provides capacity-building support to operators of small enterprises, including subsistence income generators and self-employed entrepreneurs. Activities of the BAC are conducted under the Rural Enterprises Program, which is jointly funded by the government of Ghana, the 
International Fund for Agriculture Development (IFAD), and the African Development Bank (AfDB). It is one of numerous projects across the country that are born out of the public/private, local/international partnerships that are in vogue. As part of its mandate, the BAC supports lending institutions as well as individual entrepreneurs. Overall, the aim of these trainings is to equip the borrowers with technical and managerial skills and attitudes that will enable them to improve their productivity and income, creating a sort of "neoliberal subjectivity" (James 2014:216). The involvement of the BAC also signals the interest of the state in promoting this neoliberal ethic within the Ghanaian workforce. It is the same sort of collaboration between public and private institutions that has been observed in other developing countries in the last few decades. In Bolivia, for example, women's microcredit NGOs work to produce "gendered citizens who are 'empowered' to access formal markets on certain terms, and who do not expect the state to provide them with social rights" (Lazar 2004:315).

However, the reality is that borrowers do not always adhere to these tenets and sometimes use part of their loans for the material needs of their dependents. It is in discharging these obligations that they become useful to others and attain the personhood to which they aspire. In such circumstances, the need to earn a higher income is not lost on the women, but the reality is that the immediate demands on their resources make it difficult for them to defer consumption to invest the entire loan amount in their businesses. Repaying bank loans is just one among many obligations that they juggle amid the uncertainties of their trade. This behavior puts them at odds with the neoliberal logic under which the lending institutions operate. But the reality is that their noncompliance is more a function of the impracticality of the demands made on them, given the context of their lived experiences.

The flexibility with which the market women function makes it extremely difficult for them to follow the strict timelines of the MFIs. Some of their own customers buy from them on credit and only make intermittent payments at irregular intervals. This is particularly the case with the wholesalers who sell in bulk to other traders. Typically, on a late afternoon of a non-market day, a trader would send her child around to the houses of people who owed her money, sometimes with a written list of names and corresponding amounts owed. On a few occasions I went along to help with the collection, and I observed that rarely did people pay the full amount at once. A good number of them usually asked for more time, offering various excuses for their inability to pay. It was difficult for traders in this position to make payments to the MFI on the exact date stipulated on the loan form.

Therefore, the reality for many market women is that they are constantly in fear of defaulting on their loans. Owusuwaa summarized the situation this way: "When the week comes to an end and you don't have enough money to pay, you become apprehensive." 4 According to Agya Osei, who helped his wife to sell at the Kokote Market, it was not difficult to keep up with the payments at the beginning of a loan cycle. However, as time passed, it became more difficult to cope with unexpected expenditures or emergencies. This 
was true for most of the traders I spoke with. One of the ways in which they tried to forestall the cash shortfalls was by reserving part of the loan money for the difficult times. They would use this money to pay the bank in the times when they failed to make enough sales or had to deal with unexpected expenditures. For Afriyie, who sold charcoal in bulk to retailers, this strategy was also useful when she was away on long trading trips. She would leave the money behind with her children to make the weekly bank payments on her behalf. In spite of these measures, traders usually ran out of cash before the loan cycle was over, and they found it difficult to keep up with the strict repayment schedule.

In Tiwaa's loan group, for instance, the loan agreement stipulated that the weekly payments were to be made on Fridays. Failing this, the lending institution could charge extra interest on the defaulting amount "as well as late payment fee of 2 percent of gross loan amount." The pressure to make the weekly payments was enormous, as the group was collectively responsible for the payment. In addition, each group member was required to operate a savings account with the MFI. This arrangement was common to most of the lending institutions operating in the Offinso area. The fear of defaulting on these commitments was something that constantly plagued the market women. When I interviewed Abena, who was a member of Tiwaa's loan group, she was adamant that her third loan cycle with the group would be her last. Her reason for this decision was that the weekly payment deadline came too quickly, and she found it hard to keep up with the payments. She baked and sold bread from her home in Offinso New Town; but the bank loan was not meant to be invested in her business. She had used it for an unspecified family emergency. A few months later, I saw her gesticulating wildly in front of the MFI office. She was visibly upset and kept complaining about the penalty that was being charged on her group for late payment. Later that morning, when the eight women in the group met to discuss their predicament, Tiwaa, as group leader, informed them that the money in her account had already been impounded and that on the day she found out she was so shocked that when she went back to her room she wept. She told me a few days later:

One day I walked into the bank to make a withdrawal. When I got there the girl checked and said, "Sister Tiwaa you don't have any money in your account." And I said, "No I have money in it." Then she said that the bank had seized the money because I'm the group leader and we failed to make our payment on time last week. ${ }^{5}$

During the same interview, Tiwaa mentioned to me that some of her group members borrowed simultaneously from other lending institutions, and this made it difficult for them to honor their commitments. But I knew that she too had taken loans from other banks. In fact, I knew that she was part of another group of women who were seeking out a new loan from a bank owned by a local politician who was running for office in the upcoming 
national elections. Tiwaa had even acquired a political party membership card to aid her efforts in getting that loan. For some of these women, it became a matter of taking money from one institution and paying it to another institution, usually the one whose deadline was soonest.

Compounding the situation further was the forcefulness with which lending institutions attempted to recover their loans. There were always stories among traders about loan defaulters being threatened with police arrest or having their property confiscated by the lending institutions. Agya Osei related to me the story of his wife's younger sister, who defaulted on a loan and had to skip town for a while. The rest of the family had to endure constant harassment from the loan officers until the loan was fully paid. Agya Osei himself nearly came to blows with one of the staff of the MFI who came to the house to retrieve the money owed.

While the present proliferation of microfinance institutions is viewed as a form of progress, the women who take the loans themselves acknowledge that progress sometimes brings negative consequences. As Clark (2009) reports from interviews with market women, progress, or modernity (anibue), sometimes comes at a price. Although Tiwaa did not draw a direct link between sika bone and the lending institutions in her quote above, the nuances of her statement indicate that she perceived such a linkage. In this interview, she was speaking in the context of the loans she took from the MFIs for her trading activities; when she spoke about taking money and going on a trading trip, she was referring to the loan money which later fizzled out. Other informants were more explicit in drawing this link. Owusuwaa was one of these women who directly impugned wrongdoing on the part of some formal lending institutions:

... there are places, when you borrow from them, the money will perish without you knowing what you used it for. That means that you must toil to pay back the loan. You may even need to borrow from somewhere else to repay ... There are places, when you take their money, it is as if there is a spirit behind it. ${ }^{6}$

This statement appears to accuse the MFIs of perpetrating fraud against market women. It is the kind of claim that is expected in a place where historians have noted a widespread distrust of banks and the preference for individualized lending arrangements with private money lenders (McCaskie 1986:7). In the current state of increased financialization, market women have reason to be wary of banking institutions, particularly in recent years due to the proliferation of dubious financial institutions. The crisis in the microfinance sector in Ghana came to a head in the last few years, prompting the central bank to revoke the licenses of several savings and lending institutions. In 2016, 70 licenses were revoked, and a further 347 followed in 2019. ${ }^{7}$ The media coverage of these occurrences has been extensive, with one outlet labeling it "a ticking time bomb for the financial sector." 8 This has increased the element of risk for people who save with these financial institutions, and 
this further exacerbates the feeling of uncertainty that traders face. Indeed, many of the women I spoke to in Kokote Market were victims of these dubious financial institutions.

Among these women was one named Adisa, a widow who sold flour of different kinds, cooking spices, and lemons in Kokote Market. At the time of my fieldwork, her trading activities were limited to traveling once every other week to Kumasi to replenish her stock. Due to her advanced age (she claimed to be seventy), she no longer had the energy to engage in brisk business as she used to do in the years when she first took over her mother's stall in the market. She was also no longer part of the many market-level peer-to-peer savings groups which she had belonged to in the past. This was because she could not keep up with her younger colleagues, and she preferred a longerterm method of saving. The susu was now her only method of saving. Each day, except Saturdays and Sundays, she paid GHS5 (USD0.84) to the susu collector and had it recorded in a tiny passbook issued by the susu company, Promise Susu Agency. At the end of each thirty-one-day cycle, she received her accumulated savings, and the company charged her GHS5 per month for keeping her money safe. The standard charge for all contributors was one day's worth of savings, which meant that each month she received less than she put in. But this arrangement allowed her to avoid the difficulties of saving on her own. It saved her from any worries of trying to keep her coins and crumpled currency notes away from her mischievous grandchildren, she said.

Promise Susu Agency started operating in the 1990s as a single man's susu collection business. Adisa recalled how the proprietor used to come to the market himself to collect and record the amounts in his notebook. Now, decades later, he had managed to grow this small itinerant venture into a modest business with its own office. The office was identified by a large sign affixed to the top of the building, and it opened each day for business at 9:00 a.m. Inside, the office was small, with two desks and half a dozen chairs for clients. There was a small back room that was stocked with what looked like old files. On the wall, a susu collection permit and a business registration permit hung near the manager's desk. These were the accreditations that showed that the business had been properly registered and licensed to mobilize savings. Now old and frail, the founder had left the running of the business to his son. But the son also delegated daily operations to a manager who worked with a team of three mobile bankers. These mobile bankers contacted the clients in their homes and workplaces. In an interview, the manager estimated the total number of clients at the time to be over one thousand, and seventy percent of these were female market traders like Adisa.

When I first met Adisa, she was full of praise for this susu company and was happy for the services they provided her. She had saved with them for over a decade, and there had been no problems all these years. But suddenly, one day, she informed me that the company had locked its doors amid rumors that it was unable to access its bank account. Adisa was surprisingly calm when she told me this. I asked her whether she and the other affected 
traders had taken any steps to get an official explanation from the company, and she retorted: "They have closed their doors, who do you ask?" She thought that they had no way of seeking answers. In the moment, all they could hope for was that the susu collector would somehow manage to return their money to them in the future:

They say that when they get the money, they will pay us, so we're watching ... what are we doing? We can only wait, when they open the room and start work again, we will know that maybe things have been resolved. ${ }^{9}$

A year after this incident, when I completed my fieldwork, they were still waiting and had yet to hear officially from the company. The doors remained locked at the offices of Promise Susu Agency, and the market women held on to their passbooks in the faint hope that their monies would be paid someday. The incident with Promise Susu Agency was just one of many regular occurrences. Frimpomaa, whose stall was right across the aisle from Adisa's, also had plenty to say about her experiences with dubious microcredit institutions. Even when she got tired of the so-called secular institutions and opted to save with an institution that was set up by her church, she still lost money when it collapsed unexpectedly. Her husband, Agya Osei, also saved with Money Bond Microfinance, and that too disappeared with his money. The couple held three full booklets from Promise Susu Agency (meaning three months' worth of savings had been lost). From these narratives, it appears that in handling cash, saving their profits, and contracting loans from formal institutions, market women engaged in a game of chance, and winning was not always guaranteed. In an ideal situation, the savings would be the first step in the process of converting "vulnerable holdings into durational assets" (Guyer 2014:148). As I was told by a bystander during a conversation with Konadu, one of my interlocutors: "A house is the ultimate form of property. A house is more valuable than anything else."10

In this context, narratives of sika bone become part of the repertoires with which people make sense of their world. The women I interacted with in Offinso told stories of the mysterious disappearance of money. Sometimes they spoke literally about how people with sika bone targeted them in a ruse designed to syphon their clean money, as Frimpomaa explained:

Those with sika bone, when they buy your things, you won't see the money when you get home. You will be surprised. Someone can give you a large currency bill, when you get home, you won't see it. This happens to us. You can sell but you won't see the money. You may think that someone has stolen from you but that is not the case. ${ }^{11}$

Like witchcraft beliefs, the value of sika bone stories comes from the fact that they provide an opportunity to see the world as their authors and narrators do, a world fraught with uncertainty and economic challenges driven by the forces of neoliberal capitalism. 
The women's stories about loss reveal both their supernatural suspicions and their conventional coping strategies. As Tiwaa's quote indicates, when they have lost the loan money, the remaining course of action is to return repeatedly to the old and the familiar, borrowing goods from other traders for sale and returning only the capital. The Twi (the language of the Asante) verb for this long-standing practice is firi, which describes the process of borrowing material items, in this case saleable goods, as opposed to cash (bosea). Over time, a diligent trader can build herself up using the profits generated on the borrowed goods. In this sense, sika bone narratives also aid the claims-making of market women. A trader is more likely to lend extra produce to another trader if she believes that the borrower is a victim of circumstances beyond her control and not because of her own carelessness or faulty business practices. Those who waste their trading capital on frivolous consumption are derogatorily said to have "di w $\supset$ ne num"-which literally means, to spend the money on one's mouth. ${ }^{12}$

Therefore, despite the setbacks, Asante market women still strive for the ideals of economic autonomy and productivity as members of a lineage and a community. The point has been made that the ability to earn an income is very central to the role of an Asante woman, both in her lineage and in her marital context (Salifu 2020). Thus, when Konadu makes the statement: "When there is no money on you, you become like a child," she is alluding to the fact that status and reputation derive from a person's ability to participate in social life, of which material exchange is an important component. ${ }^{13}$ The import of this statement is even more significant when considered within the context of the Akan culture, in which age, maturity, and experience are highly valued, as opposed to the naivety and inexperience of childhood (Gyekye 1987:63). Therefore, it is important for market women, in their daily activities and narratives, to represent themselves as tenacious risk takers who are willing to try again and again even though money continues to elude them. They become like many other people around Africa for whom the occult is both a source of distress and a discourse that is "invoked to cope with the unsettling modern developments" (Geschiere 2015:606).

\section{Conclusion}

In this discussion about sika bone in an era of increased financialization, the focus is less on determining the veracity or otherwise of the narratives, and more on how they are utilized by market women to depict their circumstances. Inexplicable loss of profits, savings, or trading capital is attributed to sika bone, a trope that is underpinned by long-held popular beliefs in a connection between spiritual and material entities. In the context of a neoliberal capitalist world order, these old notions are applied to new actors in the form of formal banking institutions and other perceived illicit accumulators of this era. Therefore, the actions of these women, that is, the invocation of supernatural belief to characterize what should be rational economic relationships involving cash, credit, and savings, can be viewed as 
further evidence of "the enigmatic nature of millennial capitalism," a paradoxical situation where both rationality and superstition appear to flourish together (Comaroff \& Comaroff 2001:3).

In this era of increased financialization, the major economic challenges of market women include high interest rates on loans, short repayment periods, and general economic instability. These problems shape the relationship between market women and lending institutions. As products of global capitalism, MFIs endeavor to encourage the economic conduct of market women to reflect a neoliberal rationality. On their part, market women articulate their own rationalities, sometimes resulting in open confrontations with the lenders. The situation of mistrust is exacerbated by the appearance of fraudulent financial institutions, which routinely offer juicy bait, only to disappear with people's savings. Even banking institutions in good standing remain at risk of collapse. Financial stability appears to be temporary for both traders and lending institutions. In a world where events often do not seem to make sense, sika bone is as valid an explanation as any other.

\section{Acknowledgments}

I would like to thank the market women in Offinso who participated in this study. I am also grateful to Kate Skinner, Maxim Bolt, Christopher Ouma, Julie Livingston, and Katrien Pype for reading and commenting on earlier drafts of this article.

\section{References}

Adebayo, Akanmu G. 2007. "Currency Devaluation and Rank: The Yoruba and Akan Experiences.” African Studies Review 50 (2): 87-109.

Barber, Karin. 1982. "Popular Reactions to the Petro-Naira." The Journal of Modern African Studies 20 (3): 431-50.

Breckenridge, Keith. 2010. “The World's First Biometric Money: Ghana's E-Zwich and the Contemporary Influence of South African Biometrics.” Africa 80 (4): 642-62.

Britwum, Akua O. 2013. "Market Queens and the Blame Game in Ghanaian Tomato Marketing." In The Food Crisis. Implications for Labor, edited by Christoph Scherrer and Debdulal Saha, pp. 53-71. München: Rainer Hampp Verlag.

Chant, Sylvia, and Caroline Sweetman. 2012. "Fixing Women or Fixing the World? 'Smart Economics,' Efficiency Approaches, and Gender Equality in Development." Gender E Development 20 (3): 517-29 .

Clark, Gracia. 1994. Onions Are My Husband: Survival and Accumulation by West African Market Women. Chicago: The University of Chicago Press.

2004. "Managing Transitions and Continuities in Ghanaian Trading Contexts." African Economic History, Special Issue No. 32: 65-88.

—. 2009. "Consulting Elderly Kumasi Market Women about Modernization." Ghana Studies 12/13: 97-119. 
2016. "African Market Women, Market Queens, and Merchant Queens." Oxford Research Encyclopedia, African History (africanhistory.oxfordre.com). Oxford University Press USA.

Clark, Gracia, and Takyiwaa Manuh. 1991. "Women Traders in Ghana and the Structural Adjustment Program.” In Structural Adjustment and African Women Farmers, edited by Christina Gladwin, pp. 217-36. Gainesville, Florida: University of Florida Press.

Comaroff, Jean, and John L. Comaroff. 1999. "Occult Economies and the Violence of Abstraction: Notes from the South African Postcolony.” American Ethnologist 26 (2): 279-303.

Comaroff, Jean, and John L. Comaroff. 2001. "Millennial Capitalism: First Thoughts on a Second Coming." In Millennial Capitalism and the Culture of Neoliberalism, edited by J. Comaroff and J. L. Comaroff, pp. 1-56. Durham, North Carolina: Duke University Press.

Cornwall, Andrea, and Althea-Maria Rivas. 2015. "From 'Gender Equality' and 'Women's Empowerment' to Global Justice: Reclaiming a Transformative Agenda for Gender and Development." Third World Quarterly 36 (2): 396-415.

Darkwah, Akosua K. 2007. "Work as a Duty and as a Joy: Understanding the Role of Work in the Lives of Ghanaian Female Traders of Global Consumer Items." In Women's Labour in the Global Economy: Speaking in Multiple Voices, edited by Sharon Harley, pp. 206-20. London: Rutgers University Press.

Dary, Stanley, and Haruna Issahaku. 2013. "Exploring Innovations in Microfinance Institutions in Northern Ghana." Business and Economic Research 3 (1): 442-60.

Due, Jean M., and Christina H. Gladwin. 1991. "Impacts of Structural Adjustment Programs on African Women Farmers and Female-Headed Households." American Journal of Agricultural Economics 73 (5): 1431-39.

Englund, Harri. 1996. "Witchcraft, Modernity and the Person: The Morality of Accumulation in Central Malawi." Critique of Anthropology 16 (3): 257-79.

Ferguson, James. 2009. "The Uses of Neoliberalism.” Antipode 41 (S1): 166-84.

Foucault, Michel. 2008. The Birth of Biopolitics. London: MacMillan.

Garikipati, Supriya, Susan S. J. Johnson, Isabelle Guérin, and Ariane Szafarz. 2017.

"Microfinance and Gender: Issues, Challenges and the Road Ahead." The Journal of Development Studies 53 (5): 641-48.

Geschiere, Peter. 2015. "Witchcraft." InternationalEncyclopedia of the Social Ev Behavioral Sciences, 2nd edition, Volume 25: 604-10. http:/ / dx.doi.org/10.1016/B978-0-08097086-8.12165-8.

Guyer, Jane I. 2004. Marginal Gains: Monetary Transactions in Atlantic Africa. London: The University of Chicago Press.

- 2014. "Gains and Losses in the Margins of Time: From West and Equatorial History to Present-Day South Africa, and Back.” Africa 84 (1): 146-50.

Gyekye, Kwame. 1987. An Essay on African Philosophical Thought: the Akan Conceptual Scheme. Cambridge: Cambridge University Press.

James, Deborah. 2014. Money from Nothing: Indebtedness and Aspiration in South Africa. Stanford: Stanford University Press.

Lazar, Sian. 2004. "Education for Credit: Development as Citizenship Project in Bolivia." Critique of Anthropology 24 (3): 301-19.

Lazzarato, Maurizio. 2009. "Neoliberalism in Action: Inequality, Insecurity and the Reconstitution of the Social." Theory, Culture E् Society 26 (6): 109-33.

Mayoux, Linda. 2001. "Tackling the Down Side: Social Capital, Women's Empowerment and Micro-Finance in Cameroon." Development and Change 32 (3): 435-64. 
McCaskie, Tom C. 1983. "Accumulation, Wealth and Belief in Asante History I: To the Close of the Nineteenth Century." Africa 53 (2): 23-43.

— 1986. "Accumulation: Wealth and Belief in Asante History: II the Twentieth Century.” Africa 56 (1): 3-23.

- 2000. Asante Identities: History and Modernity in an African Village 1850-1950. London: Edinburgh University Press.

Norwood, Carolette. 2011. "Women, Microcredit and Family Planning Practices: A Case Study from Rural Ghana.” Journal of Asian and African Studies 46 (2): 169-83.

Oduro-Frimpong, Joseph. 2014. "Sakawa Rituals and Cyberfraud in Ghanaian Popular Video Movies.” African Studies Review 57 (2): 131-47.

Olsen, William C. 2002. "'Children for Death': Money, Wealth, and Witchcraft Suspicion in Colonial Asante." Cahiers d'Études Africaines 42 (167): 521-50.

Robertson, Claire. 1974. "Economic Woman in Africa: Profit-Making Techniques of Accra Market Women.” The Journal of Modern African Studies 12 (4): 657-64.

- 1983. "The Death of Makola and Other Tragedies." Canadian Journal of African Studies 17 (3): 469-95.

Salifu, Jovia. 2020. "Kinship and Gendered Economic Conduct in Matrilineal Offinso, Ghana." Africa 90 (4): 683-700.

Valencia-Fourcans, Lidia, and Roberta Hawkins. 2015. "Representations of Women in Microcredit Promotional Materials: The Case of Espoir Ecuador." Journal of International Development. Retrieved 6 March, 2016 from http://onlinelibrary. wiley.com/doi/10.1002/jid.3136/epdf.

Van den Berg, Marrit M., Robert Lensink, and Roselia Servin. 2015. "Loan Officers' Gender and Microfinance Repayment Rates.” The Journal of Development Studies 51 (9): 1241-54.

Walsh, Andrew. 2003. “'Hot Money' and Daring Consumption in a Northern Malagasy Sapphire-Mining Town." American Ethnologist 30 (2): 290-305.

Wan, Mimi Y. 2001. "Secrets of Success: Uncertainty, Profits and Prosperity in the 'Gari' Economy of Ibadan, 1992-94.” Africa 71 (2): 225-52.

\section{Notes}

1. Interview with Tiwaa, Offinso, December 29, 2016.

2. Interview with Tiwaa, Offinso, August 14, 2017.

3. Interview with Tiwaa, Offinso, December 29, 2016; portions cited in Salifu (2020:695).

4. Interview with Owusuwaa, Offinso, February 21, 2017.

5. Interview with Tiwaa, Offinso, March 6, 2017.

6. Interview with Owusuwaa, Offinso, February 21, 2017.

7. For the revocation of licenses in 2016, see https://fic.gov.gh/bank-of-ghana-bog-" https:/ / fic.gov.gh/bank-of-ghana-bog-revokeslicenses-of-70-money-lending-andmicrofinance-companies/

For the 2019 revocations, see https://www.graphic.com.gh/business/businessnews / full-list-of-347-microfinance-companies-whose-licences-have-beenrevoked.html.

8. https://www.graphic.com.gh/news/general-news/microfinance-companies-indistress-customers-hunt-for-directors-for-cash.html. 
958 African Studies Review

9. Interview with Adisa, Offinso, December 13, 2016.

10. Interview with Konadu, Offinso, January 21, 2017.

11. Interview with Frimpomaa, Offinso, August 4, 2017.

12. Interview with Adisa, Offinso, December 13, 2016.

13. Interview with Konadu, Offinso, January 21, 2017. 